\title{
The Niger Delta Crisis in Nigeria: Pre and Post Amnesty Situation
}

\author{
Erıng, Simon Odey, Ph.D \\ Corresponding Author: \\ Department of Sociology, Faculty of Social Sciences \\ University of Calabar, Calabar \\ GSM: 08033488197; 08050232113 \\ E-mail address: odeyering2003@yahoo.com; odeyering@gmail.com \\ Bassey, Glory Eteng \\ gloryeteng@yahoo.com \\ Odike, Ebenezer Levi \\ Department of Sociology \\ University of Calabar, Calabar - Nigeria
}

\section{Doi:10.5901/mjss.2013.v4n6p421}

\section{Abstract}

The emergence of militancy in the Niger Delta region led to problems of insecurity, pipeline vandalisation, disruption of oil output and revenues to the Nigerian government. Against this background the Federal Government initiated an Amnesty programme in 2009. The highly descriptive nature of the study necessitated the adoption of extensive desk research. This study examines critically the pre and post amnesty situation in the Niger Delta region of Nigeria. The findings show that the Amnesty extended to the militants in the area was one of the necessary steps towards resolving the restiveness in the region. In it we recommended that, it is important for government to look beyond the amnesty to address the key issues of underdevelopment (such as widespread poverty, high level of unemployment and lack of basic infrastructure and amenities and environmental degradation) in the region.

Keywords: Militancy, Amnesty situation, underdevelopment, environmental degradation and youth restiveness.

\section{Introduction}

Over the past fifty years, the Niger Delta terrain has been overrun through deliberate over exploitation carried out in total disregard of basic principles of sustainable environmental management. The ethnic unrest and conflicts of the late 1990s (examples, the ljaw, Urhobo, Ogoni and Itsekiri), coupled with a spike in the availability of small arms and other weapons, led increasingly to the militarization of the Niger Delta Region. By this time, local and state officials had become involved by offering financial support to those paramilitary groups they believed would attempt to enforce their own political agenda (Wikipedia, 2004).

The fertile ground for all of these clandestine activities of militants was layed by the activities of foreign oil corporations, that is, the multinational companies. The discovery of oil in commercial quantities by the Royal Dutch Shell in Oloibiri in 1956, in present day Bayelsa, attracted other multi-national companies such as ExxonMobil, Total Fina Elf, Agi Chevron and Texaco. The American oil giant, Chevron also discovered hers' in the Escravos Bay in 1963 and operation in production started in 1965. Elf started in 1962 at Obagi, Rivers State. Agip and Texaco commenced exploration in 1962 and 1970 respectively.

The exploration activities of all these oil companies enabled the country to export 2 million barrel per day (bpd) in 1972 (Mebbine 2000, unpublished). Since then production capacity increased tremendously, generating huge revenue to government, yet the host communities, that is, communities from which this "black gold" petroleum is gotten continue to live in abject poverty and with devastated socio-economic environment. This situation of impoverishment and heinous environmental crimes led to the emergent of agitations and contentions in the region. 
These agitations and contentions took various dimensions and approaches, but to the detriment of the people of the Region and indeed the country as a whole. At one point, (in the 60s), it was led by Jasper Isaac Boro under the umbrella of Niger Delta freedom fighters, at another time, it was championed by the late publisher, environmentalist and activist Late Ken Saro Wiwa who not only lost his life through execution alongside some members of his kinsmen. In spite of these, the condition of the people remains devastated, deplorable and unbearable leading to the emergent of militant forces that changed "the socio-economic and political dance" with devastating effect not only in the region but across the nation and even beyond as oil production and revenues went down tremendously. Many persons, including traditional leaders from the various ethnic nationalities who were seen as collaborators with the multinationals and government were killed while some oil companies were closed down, affecting seriously the revenue/profile to the federal government. This ethnic and political unrests continued throughout the 1990s and persisted to 2007 despite the conversion to democracy and the election of the Obasanjo government in 1999.

The situation gave serious concern not only to the federal government but also to the international community. It is in bid to finding solution to the pathetic condition that existed in the region, that the late President, Umaru Yar'dua declared a "State of Amnesty" in the Niger Delta Region. This paper examines examined the Amnesty programme, the sustainability of the programme, other contentious issues, and proffered solutions for the way forward.

\section{A brief background of the Niger Delta crisis}

The Niger Delta region, also referred to as the South-South geo-political zone is made up of six states - Akwa Ibom, Delta, Bayelsa, Cross River, Edo, and Rivers States. It is a region made up of a number of ethnic nationalities mainly, ljaw, Ekwere, Ibo, Efiks, Mbembe, Ejagham, Yakurr, to mention but these few. Several studies on the Niger Delta revealed a number of socio-economic crises such as environmental degradation, widespread unemployment, absolute poverty and a dearth of socio-economic infrastructure to mention but these few. (Ering \& Akpan, 2012, \& 2010; Dakjumbo, 2006, Banigo, 2005). For the most part a large majority of the people did not perceive the magnitude of their exploitation mainly because of lack of necessary information. Only few elite with the awareness challenged the status quo.

The concerns were that even though the bulk of the crude oil came from the region, the people of the area ranked among the most backward and marginalized groups in the country. The devastation cause by oil spillage and gas flaring has made it virtually impossible for the people to earn a living from their hitherto agricultural activities - farming, fishing and trading. In communities where oil exploration and production activities are carried out, the consequences are great; deforestation, erosion, acid rains, and destroyed farmlands, are the main signposts for this gift of nature. Activities of these companies caused the pollution of the creeks and destroyed aquatic lives. And when there are spillages, the losses are unquantifiable, for example, the Mobil oil spill, on Ibeno shoreline, in January 2013; and several other oil spill incidents on August $3^{\text {rd }}$ and 24th; November 9, December 16 and 19, all in 2012. Texaco oil spill and blowout caused a colossal loss of lives, destroyed lives and damaged the ecosystem of the area and destroyed the fishing gears. Adequate compensation and clean up were not done. All these aggravated the agitations which resulted to a lot of crises in the region. There were no proper Environment Impact Assessment (EIA) of the region and the obnoxious land use decree, 1978, which theoretically put the ownership of landed property on government and deprive the people of their God given resources.

In 1968 when oil production began in Oguagba in Edo, the peoples' joy was without limit; their joy knew no bounds because of the perceived benefits that oil exploration and revenues will bring. But the people were later to lament and declared thus:

Our joys have become sorrows because the oil production activities have completely destroyed the ecological systems of our clan. Aquatic life is almost completely destroyed, the soil completely eroded and flora and fauna badly affected; almost extinct. In addition, oil exploration and production activities have subjected us to devastating erosion and permanent pollution, forcing us against our will to lie permanently to a toxic atmosphere (Mebbine, unpublished, 2000:15).

Therefore the non-challant attitude of the multinational oil companies to improve on the well being of host communities through their corporate social responsibilities for the harmful effect of their activities, the uncompromising and irresponsive attitude of the Nigerian National Petroleum Corporation (NNPC) which is the federal government representative that regulates the oil industry did not go down well with the people. Consequently, it led to the restiveness 
of the people, culminating in the vandalism, disruption of oil firms operations, kidnapping and hostage taking of both local and expatriate workers of oil companies, and the seeming endless demand for ransom for huge their release.

\section{Niger Delta Crisis: Theoretical Exposition}

Two theoretical perspectives are adopted in explaining the Niger Delta situation and its allied effects, in the region. The conflict theory, and Ken Saro-Wiwa's Development Racism (Akpan, 2004). First, for Ken's "Development Racism Theory", views the situation in the Nigeria Delta, akin to a rent seeking state that collaborates with extractive industries (multi-National Oil Companies) to exploit its own people in a resource based economy. Countries like Nigeria, Sudan, Liberia, Nambia, and the Democratic Republic of Congo provide enough evidence in this regard, (Akpan, 2004).

The second is the conflict theory, which views activism, militancy, thuggery and kidnapping as products of audacious capitalism and overt selfishness that manifest in the subjugation and alienation at both micro and macro levels of society leading to surplus value for government's agencies and multinational companies operating in the region (Shell BP; Exxon Mobil, Chevron and others). This situation in Mark's view, presupposes tension between incompatible forces, provides the source of change which is realizable through unity of purpose and the different manifestations of the violent that emerged in the Niger Delta region, (Nkokocha, 2012).

The underlying assumptions of the two theories put forward above, is that conflict is inevitable in resource based economy because the rulers in such states, example Nigeria and others, mentioned above, usually connived with foreign extractive industries to exploit their own people. The attempt by the people to resist such exploitation usually leads to conflict (Ering \& Akpan, 2012). Moreso, the proceeds from the resources are not used for the benefit of the citizens, leading to high rate of poverty, widespread unemployment and lack of basic social infrastructure associated with resource based economy of the Third World countries.

This is the situation in the Niger Delta Region of Nigeria, where available evidences from extant literature show that in spite of the huge resources the country has realized over the years from crude oil, Nigeria ranks 156 out of 187 countries on the Global Human Development Index (HDI) (UN, 2011). It also shows that in spite of the huge resources being taken out of the Niger Delta Region, the many communities and people in the region still revile in object poverty, high level of unemployment and devastated environment.

\section{Niger Delta Crisis: Pre-Amnesty Situation}

The issues of the Niger Delta region are long standing ones. The region has for long remained a hotbed of political activism and agitation for minority rights. The area acquired this reputation even before the advent and discovery of oil at Oloibiri in 1956. With oil and its attendant negative impacts came more agitations and in some cases, crises of very wide proportions (that is, oil bunkering and the emergent militancy). The root of such crises was the clamour for better accommodation in the Nigerian nation, in terms of the socio-economic development of the area, which necessitated the setting up of the Henry Willink Minorities Commission by the colonial government in 1958 to look into the fears of the people of the Niger Delta as well as other ethnic minority groups in the country.

The recommendations of the Commission gave birth to the setting up of the Niger Delta Development Board (NDDB) in the 1960s. The NDDB was charged with the responsibility of bringing about rapid development of the Niger Delta region. This was not achieved as the monies allocated to it were seriously disproportional to the problem of the region and to outright discontinuation of payment to the body leaving it at the mercy of foreign donors. With the advent of civilian government of Alhaji Shehu Shagari in 1979, the people of the region were optimistic that serious consideration will be put in place to the kick-starting of the Board to meet its objective, rather in 1980, the then president Shargari created the Niger Delta Basin Development Authority (NDBDA). The concern of the administration was to ensure an even spread of development to other parts of the country even to areas which had no oil. The Agency was saddled with the responsibility of providing irrigation, drainage system, check flooding and erosion, gather hydro-meteorological data, provide portable water, widen waterways, dredge canals, and carry out soil analysis among others. This action of the president was seen as a deliberate one, as fund or revenue from oil was not adequately released for the funding of the NDBDA. This development frustrated and increased the feeling of neglect by the federal government, of the people of the Region.

However, during the Third republic 1991, serious and conscious attempts were made by the federal government to address the problems of the region. The National Assembly enacted the Revenue Act. The law made provisions for more funds to the region for development with 1.5 percent derivation fund. Due to administrative bottlenecks and 
bureaucracy, the development of the region suffered a set back until the emergence of Gen. Sani Abacha in 1993. Before now, Gen. Ibrahim Babangida established the Presidential Implementation Committee (PIC) in 1987, and consequently, the creation of Oil Mineral Producing Areas Development Commission (OMPADEC) in 1992. The committee activities did not see the light of day as its impact was never felt by the people, further aggravating the restiveness and the agitation grew by each passing day, with oil companies increasingly becoming the target of attack. The increasing vandalisation of oil pipelines and disruption of the activities of the various oil companies again led to the establishment of the Niger Delta Development Commission in 2000. With this Commission, government concern was to directly intervene in the development of the Niger Delta region. Even so, whatever appropriation or monies that were channeled to the commission ended in private pockets to the chagrin of the people it was meant for. In 2009, the Late President Umaru Yardua created the Ministry of the Niger Delta, the concern was to create a ministry evidently dedicated to the development of the region. In spite of all of these attempts, and with the dismal performance of the agencies and the ministry the activities of the militants continued unabated. The argument however, was that the federal government was playing politics with the lives of the people of the Niger Delta.

\section{The Granting of Amnesty}

The American Heritage Dictionary of the English Language, Fourth Edition (2000) defines "Amnesty" as a general pardon, especially for offences against a government (or for political offenses). It is a period during which a law is suspended to allow offenders to admit their crime without fear of prosecution. It could also refer to a situation or initiative where individual are encouraged to turn over illicit arms to the Authority (in this case the government).

In Nigeria, a state of Amnesty was declared by the former civilian President, Late Umaru Yar'dua in 2009 to the various militant groups operating in the Niger Delta Region whose social vices have bridged the peace of the Region in particular and the nation in general. It is important at this point, to identify some of these major groups and their leaders operating in the area. A few notable ones here are, the Niger Delta Peoples Volunteer Force (NDPVF); Movement for the Emancipation of the Niger Delta (MEND), Movement for the survival of the Ogoni People; Nigeria Niger Delta Vigilante, Niger Delta Liberation Front, Joint Revolutionary Council and the ljaw Youth Council. And the key leaders were Henry Okah, Asari Dokubo; Ateke Tom; Government Ekpemupolo (AKS Tompolo); Soboma George, Brutus Ebipodei, Solomon Ndigbara, Tubotamuno Angolia, John Togo, Ebikabowei Victor-Ben Godswill Tamuno and others. The Federal Government made this declaration with the aim of restoring normalcy to the oil producing area. A number of activities were planned for the many repentant militants, these included, training in various skills both within and outside the country. In most cases large sums of money were paid the leaders of the various groups. A few were given contract running into billions to protect the oil pipelines from vandalisation.

At the end of the Amnesty, that is when the Amnesty offer was closed, over 8000 militants surrendered their arms and ammunition and pledged full allegiance to the Federal Government (Akpan \& Ering, 2010). Some of the leaders of these groups were treated as kings and given juicy contracts which were into billions of naira. Regrettably, since after its declaration remarkable changes have not been made in the region, leading to a resurgence of militant activities in the region.

\section{Post-amnesty situation}

The situation in the Region after the granting of Amnesty has led to some pocket of development activities dotted around the states of the south-south. These however are a far cry from the enormity of work on ground in terms of socioeconomic needs of the people. By and large, the situation after Amnesty can be summarized as follows:

i) Amnesty granted to the militants it seems serve only as a strategy to enable the government and oil companies to continue with oil exploration in order to bring in revenue to government. This strategy the government adopted amounted to throwing money at issues affecting the Niger Delta instead of addressing them head on. Most recently, the federal government voted N56 billion for the post-amnesty programme without proper plans for its proper usage (Vitalis 2002). Considering the inflationary rate in the country, it was doubtful if the amount can do any tangible development in the region or carter for the needs of the militants. In most cases, scholars have argued that the money voted into the Amnesty programme found their ways into the pocket of the political elites for use in electioneering campaigns, others ended up in private pockets as the issues of corruption continue to grow becoming worst and entrench in the fabric of Nigeria's social life (Punch, 2013). 
ii) Amnesty did not meet the need of the people of the Delta region; it was only an act of freeing militants and not to develop the area. Amnesty is not a development act, and it has explained itself in the sense that, amnesty has been offered and yet peace has not come to the region. The people are still crying over the radio, television and newspapers. The concern of the people is for the government to come and develop the area and improve on the socio-economic lives of the people. Moreso, Amnesty itself is political that will not add value to the struggle of the Niger Delta people. Amnesty is only a political prerogative from the Federal Government to the militants over their criminal activities such as oil bunkering, pipeline vandalization, kidnapping of oil workers and what have you. It does not address the socio-economic needs of the people. Amnesty does not take care of the inequality that exist, the sprawling poverty, environmental degradation and the widespread unemployment that exist in the region.

iii) Allied to the point above, is the issue of lack of infrastructural development in the region. The Niger Delta region is suppose to be one of the most developed regions in Africa occasioned by the availability of oil. This is mostly the case as espoused by the proponent of the Basic Resource Model (Essang, 1995). There is low level of development in the region with lack of basic social amenities which have continued to engineer the activities of militant like kidnapping vandalisation of oil pipeline and platforms.

iv) Amnesty has not address the problem of oil spills, leakage and waste which has resulted in severe environmental disaster of the region. The saturation of soil with hydrocarbon content from oil spills is dismal. In addition to harming human life, vegetation such as mangrove forests is particularly susceptible to oil spills, because the soil soaks up the oil, and it is released every rainy season. The 1980 spill destroyed 340 hectares of mangroves. And all over the Delta there have been numerous reports of dying marine life of severe impact to fishing communities (Okorie, 2005).

v) High rate of unemployment, marginalization, discrimination and exploitation. The people of this region, have greater percentage of their population unemployed. And in order to meet their daily needs, they take to militancy, kidnapping, and so on. The people have been exploited, marginalized and discriminated against of their natural resources. Members of the political class scramble for the partition and sharing of the enormous wealth that comes from the oil. Even when the multinational companies seek to pay royalty to the host communities, the elite (made of chiefs, politicians and others) hide under the cloak of representing the people to divert the monies paid to their private pockets or usage.

vi) The issue of gender bias. The Amnesty or rehabilitation programme granted militants is skewed towards the male gender as if the female were not part of it. The argument here is that militancy is associated with both the male and female youth. Therefore, whatever must be done must also consider and accommodate the female gender, the children and the elderly. In order to avoid a situation where a crop of young girls or ladies could rise up to carry out another round of criminality and demand for their rights, even as it was in the Aba Riots of 1929 there is need to involve the female militant. Therefore, amnesty as a strategy must be holistic in approach and all encompassing, involving both the female gender and children. In other words efforts must be made to carry these groups along.

\section{Niger Delta Crisis: The Way Forward}

The concern of this paper is that beyond amnesty, there are core issues plaguing the region for which the militants capitalized on to cause mayhem in the region, these should be genuinely addressed. These issues will include:

(1) Tackling the problems of underdevelopment in the region. These will include strategies that will deal with the problems of infrastructural decay and the near absence of socio-economic amenities. The multi-national companies could assist government (federal and state) in providing these essential infrastructures like roads, electricity, portable water and health. This could be done through community driven development approach, (CDD). The approach espouses the participation of the local people in issues and process that concern them. The people should be allowed to identify projects, plan and execute them in collaboration with outside forces or agencies, and in this case, the government and multinational companies. The approach if well manage have the potentials of bringing about the sustainability of development projects in the region.

(2) Tied to one above, the federal government with the assistance of the oil companies should evolve models that will deal with the problems of sprawling poverty, high unemployment, mass illiteracy and the widening inequality that exist between the modern urban enclave and the rural sector. These issues are at the core of youth restiveness in the region and increasing crime rate in society. 
(3) Enhanced budgetary allocation and financial accountability at local and state levels. This has become necessary so that the monies budgeted for development projects are used for the benefit of the entire people by implementing priority projects that will impact positively on the lives of the ordinary man (in the Niger Delta).

(4) Encourage the multinational oil companies in the Niger Delta region to embark on a number of corporate social responsibilities and adhere to international best practices in the protecting of the environment. The companies must as a matter of necessity embark on the massive clean up of the environment. The region is known for its highly swampy conditions ideal for fishing economy; but after over four decades of oil spills and gas flares, much of the fishing creeks are now barren; land has been seriously damaged and reduces to wasteland. The project must be relevant to the needs and aspiration of the people. Allied to the above, multinational companies as part of their corporate social responsibilities could evolve more proactive conflict sensitive community relations strategies and demonstrate greater transparency in their community development programmes. There could be community relation structure where the companies and communities periodically discuss issues of common interest and for the symbiotic development and wellbeing of communities and oil companies.

(5) Strengthen the security arrangements in the region by improving collaboration between the police and local security including private and community based security organizations. We will recommend "predicting Policing" as a new security strategy in crime prevention. Predicting policing is a new thinking in crime prevention and policing human behaviour. It involves special and better understanding of human behaviour to know their thoughts and direction and the ability to apprehend before they manifest into crime.

(6) Government with the assistance of the multinational oil companies could evolve better capacity building strategies that will involve the youths (male and female) in the region. Such programme could include civic education, skill acquisition and participatory governance. This will involve giving grants to states and communities in the region and providing micro credits to community members through third parties. This will involve employing the services of experts to help in executing the plans for the multi-national companies.

\section{Conclusion}

The emergence of militancy in the Niger Delta Region was as a result of the negligence on the part of government and the elite in the region. The crisis in the Niger Delta region took decades to create, but the nation does not have decades within which to deal with the crisis. Dealing with the crisis must be seen within the context of reversing the fortunes of the entire region through massive infrastructural development (road, bridges, electricity) and empowering the citizens, and the cleaning up the wasteland created by the over forty years of oil spills .

\section{References}

Akpan, Felix (2004). "Niger Delta Development Commission (NDDC) and the Politics of infrastructural and Human Resource Development; A programme Evaluation of NDDC as an Intervention Regime". Ph.D Thesis at the University of Calabar.

Akpan, F. \& S. O. Ering (2010) "The Politics of Amnesty and Oil Related Conflict in the Niger Delta Region of Nigeria". European journal of Social Sciences, 17 (2) $146-153$.

Alechanu John \& Fidelis Soriwei (2013). "US Right about Nigeria's worsening Corruption" - The Punch, 17, (20, 383$), 2$.

Amange, N. B. (2008). Road to peace in the Niger Delta. Mojek Press: Port Harcourt

Banigo, A. O. (2005). Issues, Affecting the People of Niger Delta; Ekeremo Press: Port-Harcourt

Charles, J. O. (2010). Sociological theory: A historical and analytical approach on man and society, Serenity publishers: Lagos.

Dan-jumbo, K. P. (2006) Oil and Oil Spillage in the Niger Delta. Unpublished M.Sc Dissertation, Port Harcourt, Rivers State University of Science and Technology.

Ering, S. O. \& Akpan, Felix (2012). "The Politics of Fuel Subsidy, Populist Resistance and its socio-economic implication for Nigeria", Global Journal of Human Social Sciences, 2 (7), 12-19.

Essang, S. M. (1995). Institutional Arrangement and income distribution in a Primary Export Economy in Western Nigeria. Ibadan University Press: Ibadan.

Giddens, A. (2006) Sociology, 5th edition Cambridge: Polity Press.

Mebbine, H. S. (2000), (unpublished). The problem of the Niger Delta is more in their leaders than the federal government: A paper delivered at the Rivers State University of Education.

Nwokocha, Ezebunna E. (2012). "The Dynamics and Dilemmas of the Niger Delta: A Historical Discourse on Insecurity and Demographic Transition" being paper presented at NASA Conference Proceedings, at Awka, 2012. 
Okorie, A. (2005) "Nigeria oil: The Role of Multinational Oil Companies": Spring Quarter Ritzer, G. (1996). Sociological theory, 5th edition: Singapore: McGraw -Hill

Vatalis, R. (2002). Black Gold, White Crude, Diplomatic history, Beacon Press: London. Wikipedia (2004). Conflict in the Niger Delta. 
